\title{
Molecular Identification and Ecology of a Newly Discovered Population of Sun Catfish Horabagrus brachysoma from Northern Western Ghats of India
}

\author{
Unmesh Katwate, ${ }^{1}$ Rupesh Raut, ${ }^{2}$ Mayura Khot, ${ }^{3}$ \\ Mandar Paingankar, ${ }^{4}$ and Neelesh Dahanukar ${ }^{4,5}$ \\ ${ }^{1}$ Bombay Natural History Society Hornbill House, Opp. Lion Gate, Shaheed Bhagat Singh Road, \\ Mumbai 400001, Maharashtra, India \\ ${ }^{2}$ Department of Zoology, Elphinstone College, Mumbai 400032, Maharashtra, India \\ ${ }^{3}$ Central Institute of Fisheries Education, ICAR, Versova, Andheri (West), Mumbai 400061, India \\ ${ }^{4}$ Zoo Outreach Organization, 96 Kumutham Nagar, Villankurichi Road, Coimbatore 641035, India \\ ${ }^{5}$ Biological Sciences, Indian Institute of Science Education and Research, Sai Trinity, Sus Road, Pashan, Pune 411021, India
}

Correspondence should be addressed to Rupesh Raut, rupesh.raut@gmail.com

Received 19 August 2012; Accepted 16 September 2012

Academic Editors: R. Castiglia, V. Ketmaier, and D. Park

Copyright (C) 2012 Unmesh Katwate et al. This is an open access article distributed under the Creative Commons Attribution License, which permits unrestricted use, distribution, and reproduction in any medium, provided the original work is properly cited.

\begin{abstract}
Horabagrus brachysoma, thought to be endemic to the southern parts of the Western Ghats of India, is recorded for the northern parts of the Western Ghats, extending the species distribution range by $180 \mathrm{~km}$. We have confirmed the identity of the species and the fact that the species is indigenous to this area and not an artifact of recent introductions using molecular methods. Apart from the range extension we have also provided detailed analysis regarding the nature of morphometric variations between the sexes, length-weight relationship, and a brief discussion about the potential habitat requirements and threats to this species. By documenting the possible threats to this threatened and endemic species, we have commented on the possible measures to conserve the species in the wild.
\end{abstract}

\section{Introduction}

Classified among the 34 global biodiversity hotspots [1], the Western Ghats of India is rich in freshwater fish diversity with more than $40 \%$ of the species being endemic to this region [2]. On one hand while new species of freshwater fish are still being described from the Western Ghats [3-6], on the other hand recent IUCN assessments have suggested that more than $58 \%$ of the endemic freshwater fish fauna of this region is threatened due to various anthropogenic stressors [7] and needs immediate conservation attention [8]. One of the major hindrance in designing and implementing potent conservation action plans for the freshwater fish in this region is the fact that they are still least understood with respect to their distribution, life history traits, population dynamics, and ecology, while many species complexes are still awaiting for proper taxonomic evaluation [7]. Limited knowledge of distribution of several fish species and continuous description of new species suggests that the freshwater fish fauna of the Western Ghats biodiversity hotspot is subject to both the Wallacean (geographical distribution of most species is poorly understood) and Linnean (most species are still not formally described) shortfalls [9].

Horabagrus Jayaram, 1955 is an endemic catfish found only in west flowing rivers of Western Ghats of India. In the order Siluriformes the exact familial affinities of Horabagrus is still debated and traditionally it has been placed under family Bagridae [10] or Schilbidae [11-13], while the recent molecular phylogeny suggests that it should belong to a new proposed family Horabagridae [14]. The genus currently comprises of two species $H$. brachysoma (Günther, 1864) and H. nigricollaris Pethiyagoda \& Kottelat, 1994, both of which are threatened [7]. 


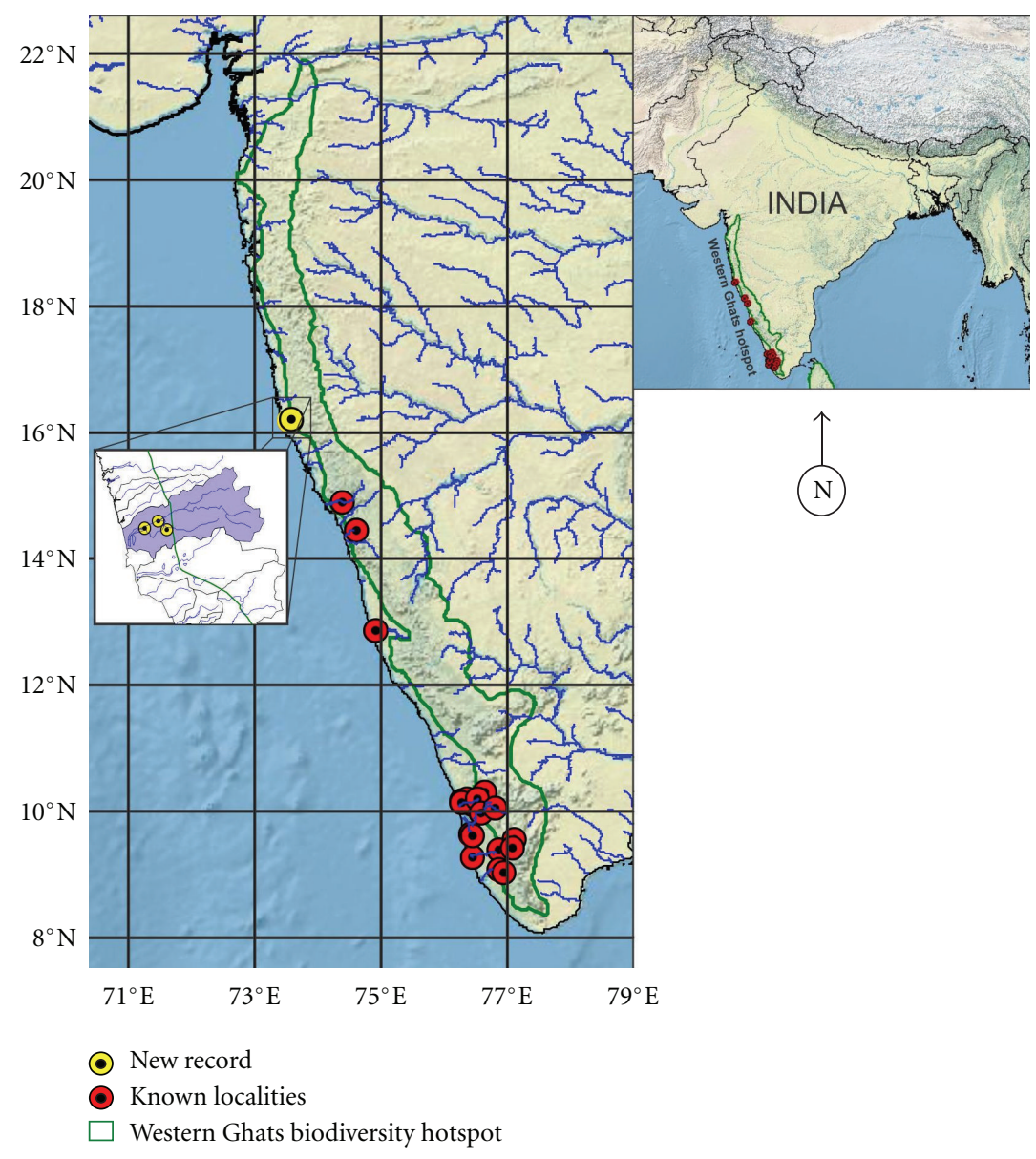

Figure 1: Map of Horabagrus brachysoma distribution along the western coast of India. Details of current localities are shown in inset.

Horabagrus brachysoma commonly called as sun catfish, yellow catfish or Günther's catfish is characterized by anterior depressed large head; obtusely rounded snout; sub terminal transverse mouth; eyes large inferiorly visible from ventral surface of head; dorsal and pectoral fin having serrated spine with 5-7 and 8-9 branched rays, respectively; adipose dorsal fin short and well separated from caudal base; ventral fin with i6 rays; long anal fin with iii23-iii28 rays and a distinct coloration with brownish back dorsal side, pale yellow on sides, white belly, a thick black shoulder spot and semilunar thick black ring at caudal base $[12,15]$. The species is heavily targeted by artisanal fishermen in inland waters of southern Western Ghats because of which it has now become vulnerable to overexploitation [16-18]. Multiple stress factors like overexploitation of wild stock for commercial fishery and international aquarium pet trade, habitat alteration, pollution, and minimum population doubling time have resulted in population decline of $H$. brachysoma in its native occurrence ranges and as a result of which this species has been listed as Vulnerable in IUCN Redlist [19]. Till date distribution of H. brachysoma was restricted from west flowing rivers of Kerala and Karnataka part of Western Ghats $[19,20]$ (Figure 1).

In the current paper we document the occurrence of $H$. brachysoma further north in Western Ghats of Maharashtra, with further studies regarding the molecular analysis (for taxonomic identification and molecular divergence), morphometry, length weight relationship, and behavioral aspects of this species based on in situ underwater observations. We have also documented the threats to the newly discovered population.

\section{Materials and Methods}

2.1. Study Area. Field surveys were conducted in Gad River basin (Figure 1) of Sindhudurga District located in south Konkan region of Maharashtra. Gad River is one of the west flowing rivers in northern Western Ghats which lies between $16^{\circ}$ to $16^{\circ} 20^{\prime} \mathrm{N}$ latitude and $73^{\circ} 30^{\prime}$ to $74^{\circ}$ longitude. Gad River originates from the hilly ranges of Sahyadri at an elevation about $600 \mathrm{~m}$ above sea level and drains in Arabian Sea at Malvan. The Gad River drains about 890 sq. km area in Sindhudurga District, overall passage length of Gad River from its origin to its outfall is $66 \mathrm{~km}$. The present study was conducted in perennial second-order streams of Gad River near Bagayat village ( $16^{\circ} 09^{\prime} 04.35^{\prime \prime} \mathrm{N}$ and $\left.73^{\circ} 33^{\prime} 04.7^{\prime \prime} \mathrm{E}\right)$.

2.2. Specimen Collection and Behavioral Study. Occurrence of H. brachysoma in streams of Gad River near Bagayat was 
first observed opportunistically in December 2010 during night fish sampling. After proper identification of a single specimen by using available taxonomic literature $[12,13,21]$ subsequent field surveys were conducted in the month of October to November 2011. Samplings were performed by using local fishing nets like monofibril gill net, cast net, and local fishing traps in between down and midnight time (5.30 pm to 12.00 midnight). Representative 18 specimens were collected for morphometric and molecular phylogeny study. The specimens were preserved in $4 \%$ formaldehyde. Ten preserved specimens from study area are deposited in the museum of Bombay Natural History Society, Mumbai under the accession number BNHS FWF 1 to BNHS FWF 10. Four specimens are deposited in the museum collection of Wildlife Information Liaison Development, Zoo Outreach Organization, Coimbatore (WILD) under the accession numbers WILD-12-PIS-020 to WILD-12-PIS-023. Four specimens are deposited in the Zoological Survey of India, Western Regional Centre, Akurdi, Pune under the accession numbers $\mathrm{P} / 3059$.

In situ underwater observations in shallow clear stream water were performed in day as well as night time by using underwater mask and snorkel. Night time observations were performed by using UK vision head lamp. Ten minute no motion buffer time were taken by observer after entrance in the stream water to avoid human interference in natural behavior of fishes. Minimum body movements were maintained during snorkel study.

2.3. Morphometric Analysis and Length-Weight Relationship. Morphometric and meristic data were recorded following [13] for 36 morphometric and four meristic characters (Table 1). We performed the morphological analysis on the formalin-preserved specimens. Measurements were taken point to point using dial calipers (Mitutoyo No 505626, Japan) to the nearest hundredth of an inch and then converted to millimeters. Measurements of body parts are reported as percentage of standard length (SL) and measurements of subunits of head are reported as percentage of head length (HL). Males and females were identified based on external genitalia, and morphometry of males and females was recorded separately. To understand whether the males and females differed in their morphometry we performed a Principle Component Analysis (PCA) on data expressed as \%SL. We performed PCA on the correlation matrix in a freeware PAST [22].

The weight of the specimen was determined to the nearest $0.01 \mathrm{~g}$ using an electric balance (Anamed MX-7210A, India). We plotted length and weight of the fish to determine the power of the length-weight relationship $W=a L^{b}$, where $W$ is the weight, $a$ is the normalization constant, $L$ is the length, and $b$ is the scaling power. The null hypothesis that $b=3$ was tested using $t$-test as described by Zar [23].

2.4. DNA Isolation and Molecular Identification. Muscle tissue was harvested from two specimens, one male (WILD-12-PIS-021) and one female (WILD-12-PIS-023) and was preserved in absolute Ethanol. The tissue was digested at $60^{\circ} \mathrm{C}$ for two hours using the STE buffer
(0.1 M NaCl, $0.05 \mathrm{M}$ Tris-HCl, $0.01 \mathrm{M}$ EDTA, 1\% SDS) with $15 \mu \mathrm{L}$ Proteinase $\mathrm{K}(20 \mathrm{mg} / \mathrm{mL})$ per $500 \mu \mathrm{L}$ of STE buffer. DNA was extracted using conventional phenolchloroform method and resuspended in nuclease-free water. Polymerase chain reaction was performed to amplify two mitochondrial genes, cytochrome oxidase subunit I (cox1), and cytochrome b $(c y t-b)$. Gene coxl was amplified using forward primer FishF1 (5'-TCAACCAACCACAAAGACATTGGCAC- $3^{\prime}$ ) and reverse primer FishR1 (5'-TAGACTTCTGGGTGGCCAAAGAATCA-3') [24], while $c y t-b$ gene was amplified using the forward primer L14724 ( $5^{\prime}$-GACTTGAAAAACCACCGTTG- $\left.3^{\prime}\right)$ and reverse primer H15915 (5'-CTCCGATCTCCGGATTACAAGAC-3') [25]. PCR reaction was performed in a $25 \mu \mathrm{L}$ reaction volume containing $5 \mu \mathrm{L}$ of template DNA ( $\sim 200 \mathrm{ng}$ ), $5 \mu \mathrm{L}$ of $5 \mathrm{X}$ reaction buffer (100 mM Tris pH 9.0, $500 \mathrm{mM} \mathrm{KCl,} 15 \mathrm{mM} \mathrm{MgCl}_{2}$, $0.1 \%$ Gelatin), $3 \mu \mathrm{L}$ of $25 \mathrm{mM} \mathrm{MgCl}_{2}, 1 \mu \mathrm{L}$ of $10 \mathrm{mM}$ dNTPs, $1 \mu \mathrm{L}$ of each primer, $0.5 \mu \mathrm{L}$ Taq polymerase, and nuclease free water to make the volume $25 \mu \mathrm{L}$. The thermal profile was 10 minutes at $94^{\circ} \mathrm{C}$, and 35 cycles of 1 minute at $94^{\circ} \mathrm{C}, 1$ minute at $52^{\circ} \mathrm{C}$ (for $\left.c y t-b\right)$ or 1 minute at $54^{\circ} \mathrm{C}$ (for $\operatorname{cox} 1$ ) and $2 \mathrm{~min}$ at $72^{\circ} \mathrm{C}$, followed by final extension of $10 \mathrm{~min}$ at $72^{\circ} \mathrm{C}$. Amplified DNA fragments were purified using the "Promega Wizard Gel and PCR clean up" system and sequenced. The purified PCR products were sequenced using ABI prism 3730 sequencer (Applied Biosystems, USA) and Big dye terminator sequencing kit (ABI Prism, USA). Sequences were edited manually using BioEdit [26]. Sequences were submitted to GenBank under the accession numbers JX460967 and JX460968 for cox1 and JX460962 and JX460969 for $c y t-b$. Sequences were analyzed using BLAST tool [27].

We retrieved additional sequences on other related species from NCBI (http://www.ncbi.nlm.nih.gov/) GenBank database (Horabagrus brachysoma coxl: HQ009501, HQ009502, EU490864, EF014947, HM579863; H. brachysoma cyt-b: EU490913, GQ398123, HM579856; H. nigricollaris cox1: HQ009503, HM579861; H. nigricollaris cytb: HM579857, GQ398127; Mystus bocourti cox1: JQ420129; M. bocourti cyt-b: EU490912; Glyptothorax poonaensis cox1: JN092397; G. poonaensis cyt-b: JN092396). Sequences were aligned using MUSCLE [28]. Molecular phylogeny was performed using the freeware MEGA 5 [29]. Best fit model for nucleotide substitution was selected from 24 models available in MEGA 5 based on minimum Akaike Information Criterion (AIC) value [30]. Phylogenetic trees were built using four methods, namely, maximum likelihood (ML), maximum parsimony (MP, close-neighbor-interchange algorithm), minimum evolution (ME), and neighbor joining (NJ, maximum composite likelihood method). Reliability of the phylogenetic tree was estimated using bootstrap values run for 1000 iterations. Evolutionary divergence between the sequences was computed using maximum composite likelihood method with bootstrap values run for 1000 iterations.

\section{Result and Discussion}

3.1. Taxonomic Identification and Molecular Phylogeny. Detailed morphological characters for Horabagrus brachysoma provided by Günther [15] and Jayaram [10, 12] matched 
TABLE 1: Morphometric and meristic data of Horabagrus brachysoma.

\begin{tabular}{|c|c|c|c|c|}
\hline \multirow{2}{*}{ Character } & \multicolumn{2}{|c|}{ Male $(n=13)$} & \multicolumn{2}{|c|}{ Female $(n=5)$} \\
\hline & Average (sd) & Min-Max & Average (sd) & Min-Max \\
\hline \multicolumn{5}{|l|}{ Morphometric } \\
\hline Total length (mm) & $53.76(4.47)$ & $48.1-64.3$ & $53.33(1.4)$ & $51.9-55.6$ \\
\hline Standard length, SL (mm) & $42.42(3.59)$ & $38.1-50.8$ & $42.84(0.94)$ & $41.8-44.3$ \\
\hline \multicolumn{5}{|l|}{$\% \mathrm{SL}$} \\
\hline Head length, HL & $31.11(1.71)$ & $26.3-33.6$ & $30.04(1.31)$ & $28.6-31.7$ \\
\hline Depth of body at dorsal fin origin & $23.73(1.22)$ & $21.9-25.9$ & $21.85(0.92)$ & $21.1-23.2$ \\
\hline Depth of body at anus & $18.97(0.72)$ & $17.7-20.3$ & $17.25(0.66)$ & $16.7-18.4$ \\
\hline Width of body at dorsal fin origin & $16.25(0.76)$ & $15.4-17.9$ & $15.16(1.37)$ & $14.0-17.3$ \\
\hline Width of body at anus & $10.13(0.62)$ & $9.1-10.9$ & $9.47(0.51)$ & $9.1-10.3$ \\
\hline Predorsal length & $37.59(1.4)$ & $35.6-40.8$ & $37.8(1.09)$ & $36.4-38.9$ \\
\hline Dorsal origin to caudal distance & $63.16(1.79)$ & $60.4-65.8$ & $62.58(1.33)$ & $61.2-64.5$ \\
\hline Prepectoral fin length & $23.99(0.66)$ & $22.6-24.7$ & $27.53(1.33)$ & $26.1-29.4$ \\
\hline Preventral fin length & $51.53(1.29)$ & $48.8-53.4$ & $52.96(1.07)$ & $51.8-54.2$ \\
\hline Preanal fin length & $61.92(1.24)$ & $59.8-64.0$ & $64.28(1.35)$ & $62.8-66.3$ \\
\hline Preanus length & $59.01(1.27)$ & $56.7-60.9$ & $59.99(2.4)$ & $57.8-64.1$ \\
\hline Ventral fin to anus distance & $7.55(0.58)$ & $6.5-8.5$ & $7.57(0.77)$ & $7.1-8.9$ \\
\hline Anus to anal fin distance & $3.73(0.4)$ & $3.0-4.5$ & $4.03(0.59)$ & $3.4-4.7$ \\
\hline Dorsal fin length & $25.25(1.64)$ & $21.6-27.5$ & $23.97(1.94)$ & $21.7-26.1$ \\
\hline Length of dorsal fin base & $10.79(0.63)$ & $10.0-12.3$ & $9.82(1.3)$ & $8.3-11.9$ \\
\hline Pectoral fin length & $22.92(1.08)$ & $21.3-25.3$ & $22.67(0.79)$ & $21.5-23.5$ \\
\hline Ventral fin length & $12.69(0.87)$ & $11.1-14.2$ & $12.36(1.43)$ & $10.4-14.4$ \\
\hline Length of anal fin base & $25.47(0.9)$ & $23.7-26.6$ & $24.69(1.36)$ & $23.2-26.9$ \\
\hline Caudal peduncle length & $14.46(1.16)$ & $13.2-16.3$ & $13.87(1.06)$ & $12.9-15.3$ \\
\hline Caudal peduncle depth & $10.24(0.54)$ & $9.6-11.0$ & $9.53(0.52)$ & $8.7-10.1$ \\
\hline Dorsal fin to adipose fin distance & $31.39(1.82)$ & $28.3-35.2$ & $30.38(2.11)$ & $28.6-33.6$ \\
\hline Adipose fin length & $10.9(1.39)$ & $8.3-12.6$ & $10.87(0.71)$ & $10.1-11.7$ \\
\hline Adipose fin base length & $6.13(0.93)$ & $5.2-8.3$ & $5.91(0.66)$ & $5.3-7.0$ \\
\hline Postadipose distance & $17.87(0.96)$ & $16.4-19.5$ & $17.23(0.81)$ & $16.2-18.1$ \\
\hline Outer maxillary barbel length & $22.6(1.86)$ & $19.7-25.6$ & $15.4(4.1)$ & $11.9-21.2$ \\
\hline Outer mandibular barbel length & $20.45(1.89)$ & $16.8-22.9$ & $13.25(2.19)$ & $10.9-16.9$ \\
\hline Inner mandibular barbel length & $16.03(2.45)$ & $10.9-19.3$ & $8.93(1.94)$ & $7.1-11.3$ \\
\hline Nasal barbel length & $17.6(1.57)$ & $14.5-20.0$ & $8.57(1.05)$ & $7.7-10.1$ \\
\hline \multicolumn{5}{|l|}{$\% \mathrm{HL}$} \\
\hline Head depth & $57.15(3.01)$ & $54.2-63.2$ & $65.56(3.58)$ & $60.0-68.8$ \\
\hline Head width & $72.67(4.44)$ & $66.0-83.6$ & $82.16(2.71)$ & $78.0-85.2$ \\
\hline Eye diameter & $21.57(0.95)$ & $20.3-23.5$ & $24.86(1.68)$ & $23.1-27.3$ \\
\hline Snout length & $25.22(2.66)$ & $21.1-29.1$ & $21.16(2.26)$ & $18.6-24.2$ \\
\hline Interorbital length & $49.82(2.05)$ & $45.7-53.3$ & $43.33(4.21)$ & $37.9-48.6$ \\
\hline Gape of mouth & $46.57(2.81)$ & $42.8-50.7$ & $43.43(2.9)$ & $39.8-46.9$ \\
\hline \multicolumn{5}{|l|}{ Meristic } \\
\hline Dorsal fin rays & \multicolumn{2}{|c|}{ I 5-6 } & \multicolumn{2}{|c|}{ I 5-6 } \\
\hline Pectoral fin rays & \multicolumn{2}{|c|}{ I 7-8 } & \multicolumn{2}{|c|}{ I 7-8 } \\
\hline Ventral fin rays & \multicolumn{2}{|c|}{ i5 } & \multicolumn{2}{|c|}{ i5 } \\
\hline Anal fin rays & \multicolumn{2}{|c|}{ iii22-23 } & \multicolumn{2}{|c|}{ iii22-23 } \\
\hline
\end{tabular}

perfectly with the specimens collected in the current study (Figure 2) indicating that the specimens in the current collection were conspecific with $H$. brachyscoma. However, while all the morphometric and meristic counts of the current collection were in the prescribed range for
$H$. brachysome as provided by Jayaram [10, 12] our specimens were small sized (maximum $50.8 \mathrm{~mm} \mathrm{SL}$ ) as compared to the adult sizes recorded by studies in Kerala ( $150 \mathrm{~mm} \mathrm{SL}$ ) [16]. Therefore, we further confirmed the identity of the current collection using molecular methods. 


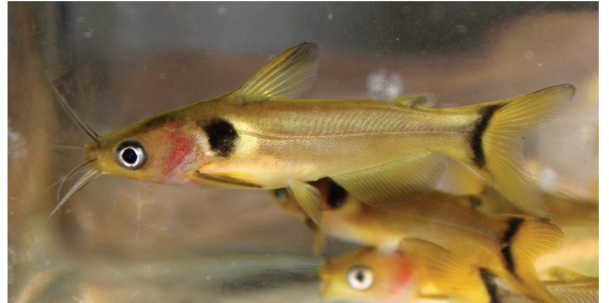

Figure 2: Horabagrus brachysoma collected from Bagayat stream in Gad River basin.

Model Test in MEGA 5 [29] suggested that models HKY+ $\mathrm{G}(\mathrm{AIC}=2685, \ln L-1318, \mathrm{Gamma}=0.1273)$ and $\mathrm{GTR}+\mathrm{G}$ $(\mathrm{AIC}=5220.85, \ln L-2586.36, \mathrm{Gamma}=0.38292)$ explained the nucleotide patterns in the cox- 1 and $c y t-b$ gene sequences, respectively. Phylogenetic trees based on all four methods (ML, MP, ME, and NJ) showed similar tree topologies. A consensus phylogenetic tree (Figure 3) that compared known sequences of Horabagrus with the current collection, suggested that the specimens in our collection were closely related to $H$. brachysoma. This was further supported by the low genetic distances between the current specimens from the known $H$. brachysoma sequences (genetic distance, cox1: $0.006 \pm 0.005, c y t-b: 0.013 \pm 0.004$ ) as compared to $H$. nigricollaris sequences (genetic distance, cox1: $0.041 \pm 0.019$, $c y t-b: 0.024 \pm 0.006)$. While the cox 1 gene sequences showed little deviations from the known sequences (Figure 3(a)) the $c y t-b$ gene sequences showed that the specimens in the current study formed a different cluster, which was supported with high bootstrap value (Figure 3(b)). However, based on the low values of branch lengths in ML (branch length 0.00495) as compared to the variation in the southern Indian populations of $H$. brachysoma (mean branch length 0.002942 with standard deviation 0.000949 ) indicates that the specimens in our collection are not phylogenetically drastically distinct from the known $H$. brachysoma. The fact that the current specimens show some phylogenetic deviation also vouch for the fact that the current population is not just a recent introduction from southern Western Ghats.

3.2. Distribution and Population Status. Günther [15] described $H$. brachysoma as Pseudobagrus chryseus from Cochin. Many researchers have reported occurrence of $H$. brachysoma from Kerala and Karnataka parts of Western Ghats $[19,20]$. In the Kerala state H. brachysoma has been found to be reported from Chalakudy, Periyar, Meenachil, Manimala, Pampa, Moovatupuzha, Achenkavil rivers as well as from Vembanad Lake, Shastham Lake and Kale wetland [16-19]. At the northern most proximity of Western Ghats $H$. brachysoma have been recorded from Nethravati, Kali and Aghanashini rivers of Karnataka [20]. Current report of $H$. brachysoma from Maharashtra extends the northern most limits of the species by approximately $180 \mathrm{~km}$ (Figure 1). Even though quantitative data is not available regarding the population status of the species in the new locality, it is a fairly common species.
3.3. Morphometric Analysis and Length-Weight Relationship. Morphometry of female and male Horabagrus brachysoma is provided in Table 1. PCA revealed the sexual dimorphism in the female and male H. brachysoma (Figure 4(a)). Males and females were separated on the first PCA axis which explained $32 \%$ of the total variation in the data. As a percent of SL the first PCA axis had high positive correlations for eigenvectors related to length of different types of barbel, caudal peduncle depth, interorbital distance, and snout length and high negative correlations for head depth, head width, eye diameter, prepectoral fin length and preanal fin length. Thus, as a percent of SL, males had longer barbels, deeper caudal peduncle, wider interorbital distance, and longer snout as compared to females. While, as a percent of SL, females had higher body depth, head width, head depth, eye diameter, prepectoral fin length, and preanal fin length. Prasad et al. [16] have also mentioned that the male and female have sexual dimorphism; however, to our knowledge there are no previous attempts to actually document the nature of this sexual dimorphism.

Power of the length-weight relationship (Figure 4(b)) of the collected specimens was $2.7716(\mathrm{SE}=0.3968)$, and it was not significantly different from cubic value $(t=0.5755$, $\mathrm{df}=16, P=0.5729)$. Anvar et al. [31] suggested that the power of length-weight ranged between 2.7623 and 3.17968 in the case of specimens collected from Chalakudy River in Kerala. Our report is within the same range. Anvar et al. [31] further suggested that the slope of males and females differed significantly. However, due to very small sample size for females we could not check the gender difference in the current study.

3.4. Behavioral Observation. Several stream habitats like runs, riffles, pools, and adjacent aquatic vegetation were scanned for presence of $H$. brachysoma. In first attempt of snorkeling during day time we failed to observe any active individual of H. brachysoma. During further extensive exploration in assistance with local fishermen we could see shoals of $\mathrm{H}$. brachysoma refuge inside submerged roots of Pundanus vegetation along stream banks (Figures 5(a) and 5(b)). Shoals of individuals of $H$. brachysoma could be seen during snorkeling. Mature full grown individuals of $H$. brachysoma were not recorded in entire study. Shoals of $H$. brachysoma have been found to be inactive during day time. In the early down time $(1730 \mathrm{~h}-1830 \mathrm{~h})$ remarkable activity of hidden individuals of $\mathrm{H}$. brachysoma was recorded. Emergence of these cat fishes began from dusk. After sunset all individuals started emerging in shoals and were seen searching for food. Approximately 30-50 individuals were recorded in single shoal. During night shoals of $H$. brachysoma were found to be occupying all niches present in streams for feeding and foraging. In night time individuals of $H$. brachysoma were mostly found to be feeding on crustaceans present in leaf litter. During early morning dives very few individuals were seen moving and hiding in Pundanus roots. Underwater observations well demarcate nocturnal foraging and feeding behavior of $H$. brachysoma. Our study also indicates that dense Pundanus vegetation across the stream banks is found to be excellent microhabitats for $H$. brachysoma to take 


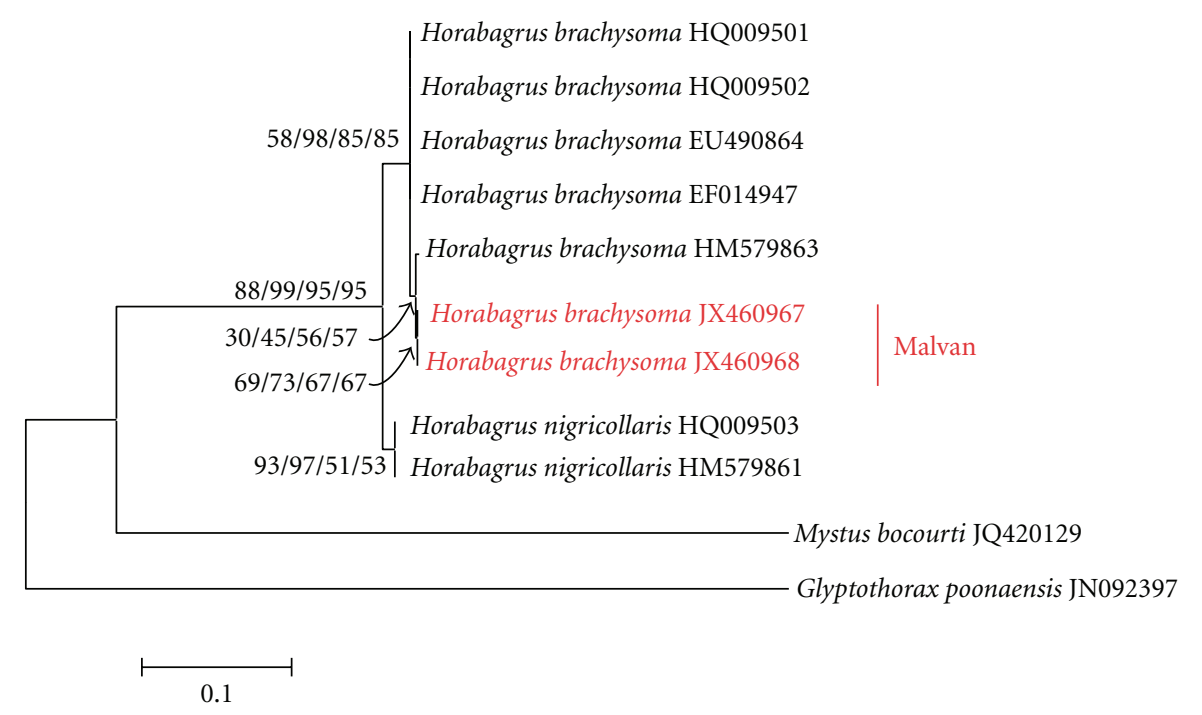

(a)

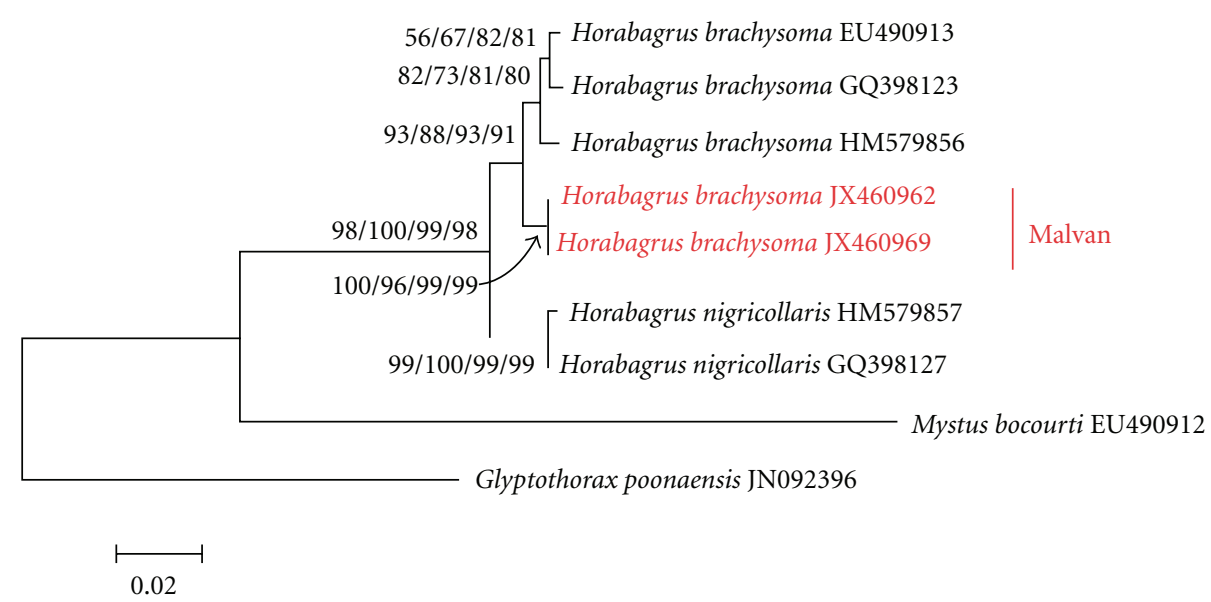

(b)

Figure 3: Phylogenetic position of Horabagrus brachysoma from Malvan compared to known cox1 (a) and cyt-b (b) gene sequences. Maximum likelihood trees, based on nucleotide substitution models given in the text, are shown in the following figures. Bootstrap values are provided for maximum likelihood/maximum parsimony/minimum evolution/neighbor joining methods run for 1000 iterations. GenBank accession numbers are provided after the species name. Mystus (family Bagridae) and Glyptothorax (family Sisoridae) are used as outgroups following Sullivan et al. [14]. Specimens in the present study are highlighted in red.

refuge in day time. As per local fishermen knowledge small streams like Bagayat in Gad River basin have abundant Pundanus vegetation and mostly dominated by subadult individuals of $H$. brachysoma, adults are mostly confined to large third order and main riverine flow of Gad River. Preference of Pundanus roots as a refuge microhabitat by subadult individuals of this threatened cat fish indicates that small rivulets like Bagayat are possibly breeding and nursery grounds of $H$. brachysoma. It also suggests that adults possibly track this secondary streams during breeding period in monsoon.

3.5. Threats and Conservation Measures. Various anthropogenic threats like overexploitation, habitat alteration, and pollution are already known to be major stressors for population decline of $H$. brachysoma which makes this species vulnerable [19]. It is also known that $H$. brachysoma is popular in international aquarium pet trade [32], which could be a potential threat to the species. Our personal observations and discussions with the local fisherman revealed that, locally called as "Ghag," most of the extensive fishing of $H$. brachysoma is carried out during monsoon. Monsoonal trawling ban in marine water and delicacy of $H$. brachysoma are possible reasons for this extensive fishing of Horabagrus during this season. Given that monsoon during June and July is the breeding season of the species [33], extensive fishing in early monsoon may alter the population structure of $H$. brachysoma in Gad River basin. A seasonal ban on riverine fishery during early monsoon may safeguard the viable breeding population of H. brachysoma. Extensive exploitation of wild immature population of $H$. brachysoma for aquarium trade is one of the prominent 


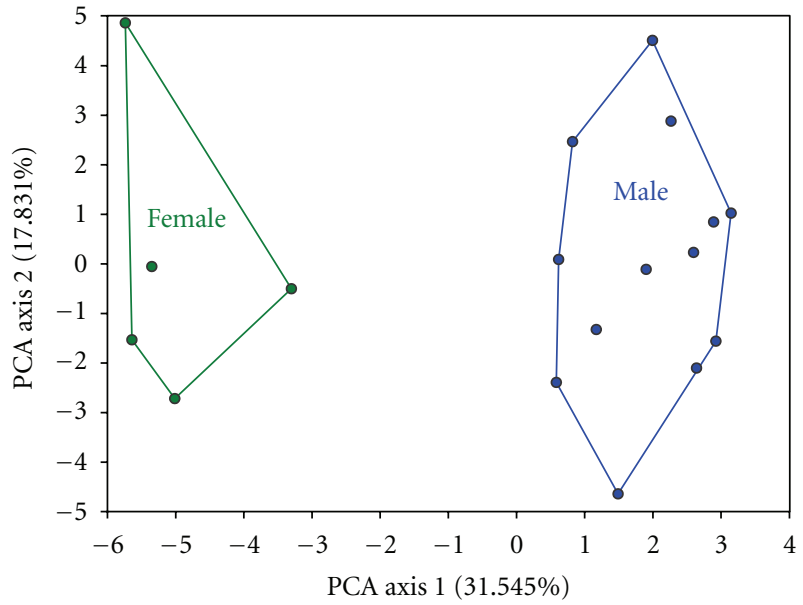

(a)

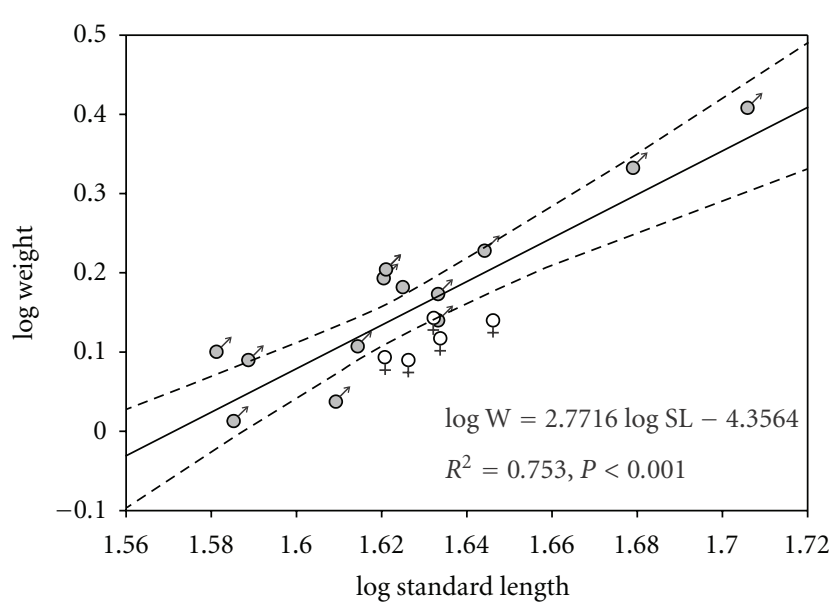

(b)

FIgure 4: Analysis of morphometric and length-weight data. (a) Principal Component Analysis (PCA) of morphometric data of male and female Horabagrus brachysoma. Percentage in parenthesis refers to percent variation explained by each PCA axis. (b) Length-weight relationship of Horabagrus brachysoma. Note that, even though males and females are marked separately, the regression is for combined data. Dashed line is $95 \%$ confidence interval.

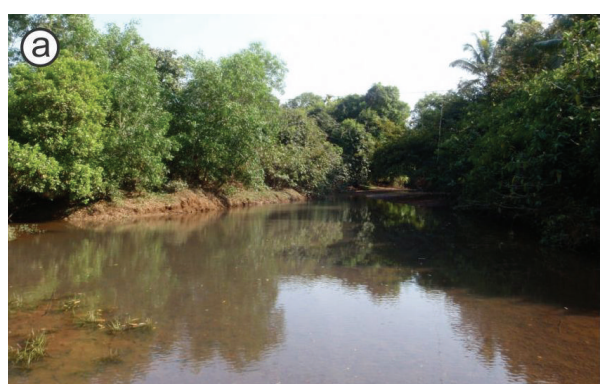

(C)

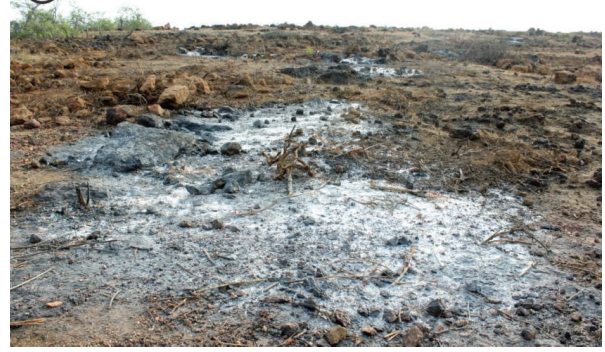

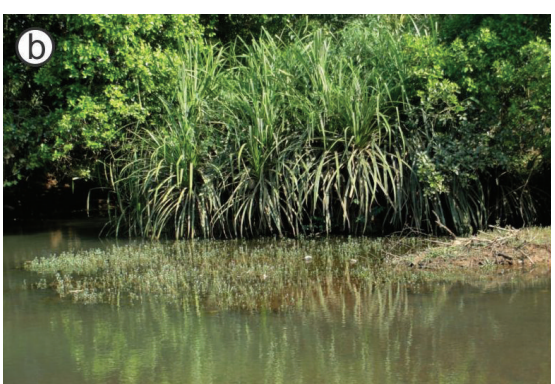

(d)

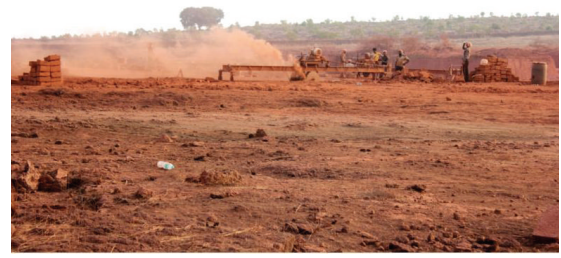

FIgURE 5: Habitat and threats to the habitat of Horabagrus brachysoma in the study area. (a) Secondary freshwater stream of Gad River near Bagayat from where H. brachysoma were collected, (b) abundant Pundanus vegetation along the stream bank provides day time refuge for H. brachysoma, (c) deforestation by slash and burn leading to heavy siltation is one of the major threats observed in study area and (d) large scale laterite boulder quarrying in Gad River basin causes changes in riparian topography.

threats we have observed in the study area. Captive breeding programs for $H$. brachysoma may overcome the problem of high demand of this species in international aquarium trade.

Industrial pollution, urbanization, mining, and laterite quarrying are increasing anthropogenic stresses in Konkan region of Maharashtra. Extensive riparian deforestation by slash and burn (Figure 5(c)) for mango and cashew cultivation, use of excessive pesticides in farms and nearby mango plantation, heavy siltation, and laterite boulder quarrying (Figure 5(d)) are major threats we have observed in study area. Recently constructed large Mahamadwadi Dam on main river channel [34] may block seasonal upstream migration of fishes. Further studies on these aspects, however, are needed to support our claims. Nevertheless, site area protection is needed to overcome these threats and conserve the population of this threatened endemic species of the Western Ghats. 


\section{Conclusions}

We have reported a new population of threatened and endemic catfish Horabagrus brachysoma extending the distribution of the species by about $180 \mathrm{~km}$ in the northern parts of the Western Ghats. We have confirmed the identity of the species using molecular methods. Along with new locality record and range extension study we have also discussed here some natural history and conservation aspects of $H$. brachysoma, which would be useful to set some conservation measure for this threatened and endemic catfish in Western Ghats. To our knowledge, in the current study, we have provided the detailed account of nature of sexual dimorphism and behavioral observations on $H$. brachysoma for the first time.

\section{Acknowledgments}

The authors thank Rajeev Raghavan, Anvar Ali, and Shrikant Jadhav for helpful discussions. They also thank members of Wild Explorers (WE), India, especially Abhijit Gharat and Harshal Rikame, for their unstinted help in the field. They are grateful to museum curators of Bombay Natural History Society, Mumbai; Zoological Survey of India, Western Regional Center, Akurdi, Pune; Wildlife Information Liaison Development, Zoo Outreach Organization, Coimbatore for help in vouchering studied specimens. U. Katwate is thankful to the Deputy Director, Conservation, Bombay Natural History Society for constant encouragement. R. Raut is thankful to the Principal, Elphinstone college, Mumbai for providing infrastructure facilities to carry out this work.

\section{References}

[1] R. A. Mittermeier, P. R. Gil, M. Hoffmann et al., Hotspots Revisited, Cemex, Mexico City, Mexico, 2004.

[2] N. Dahanukar, R. Raut, and A. Bhat, "Distribution, endemism and threat status of freshwater fishes in the Western Ghats of India," Journal of Biogeography, vol. 31, no. 1, pp. 123-136, 2004.

[3] K. Krishnakumar, F. G. Bennopereira, and K. V. Radhakrishnan, "Puntius madhusoodani (Teleosti: Cyprinidae), a new species of barb from Manimala River, Kerala, India," Biosystematica, vol. 5, no. 2, pp. 31-37, 2011.

[4] R. Britz, A. Ali, and S. Philip, "Dario urops, a new species of badid fish from the Western Ghats, southern India (Teleostei: Percomorpha: Badidae)," Zootaxa, vol. 3348, pp. 63-68, 2012.

[5] R. Britz and M. Kottelat, "Pangio longimanus, a miniature species of eel-loach from central Laos (Teleostei: Cypriniformes: Cobitidae)," Ichthyological Exploration of Freshwaters, vol. 20, no. 4, pp. 371-376, 2009.

[6] R. Britz, K. Kumar, and F. Baby, "Pristolepis rubripinnis, a new species of fish from southern India (Teleostei: Percomorpha: Pristolepididae)," Zootaxa, vol. 3345, pp. 59-68, 2012.

[7] N. Dahanukar, R. Raghavan, A. Ali, R. Abraham, and C. P. Shaji, "The status and distribution of freshwater fishes of the Western Ghats," in The Status and Distribution of Freshwater Biodiversity in the Western Ghats, India, S. Molur, K. G. Smith, B. A. Daniel, and W. R. T. Darwall, Eds., chapter 3, pp. 21-48, IUCN, Cambridge, UK and Gland, Switzerland, Zoo Outreach Organisation, Coimbatore, India, 2011.
[8] S. Molur, K. G. Smith, B. A. Daniel, and W. R. T. Darwall, Eds., The Status and Distribution of Freshwater Biodiversity in the Western Ghats, India, IUCN, Cambridge, UK and Gland, Switzerland, Zoo Outreach Organisation, Coimbatore, India, 2011.

[9] L. M. Bini, J. A. F. Diniz-Filho, T. F. L. V. B. Rangel, R. P. Bastos, and M. P. Pinto, "Challenging Wallacean and Linnean shortfalls: knowledge gradients and conservation planning in a biodiversity hotspot," Diversity and Distributions, vol. 12, no. 5, pp. 475-482, 2006.

[10] K. C. Jayaram, "Contributions to the study of bagrid fishes (Siluroidea: Bagridae): 1. A systematic account of the genera Rita Bleeker, Rama Bleeker, Mystus Scopoli, and Horabagrus Jayaram," Internationale Revue der Gesa-mten Hydrobiologie, vol. 51, no. 3, pp. 433-450, 1966.

[11] C. J. Ferraris Jr, "Checklist of catfishes, recent and fossil (Osteichthyes: Siluriformes), and catalogue of siluriform primary types," Zootaxa, no. 1418, pp. 1-628, 2007.

[12] K. C. Jayaram, Catfishes of India, Narendra Publishing House, New Delhi, India, 2009.

[13] K. C. Jayaram, The Freshwater Fishes of the Indian Region, Narendra Publishing House, Delhi, India, 2nd edition, 2010.

[14] J. P. Sullivan, J. G. Lundberg, and M. Hardman, "A phylogenetic analysis of the major groups of catfishes (Teleostei: Siluriformes) using rag1 and rag2 nuclear gene sequences," Molecular Phylogenetics and Evolution, vol. 41, no. 3, pp. 636$662,2006$.

[15] A. Günther, Catalogue of Fishes in the British Museum, vol. 5, British Museum, London, UK, 1864.

[16] G. Prasad, A. Ali, M. Harikrishnan, and R. Raghavan, "Population dynamics of an endemic and threatened Yellow Catfish Horabagrus brachysoma (Günther) from Periyar River, southern Western Ghats, India," Journal of Threatened Taxa, vol. 4, no. 2, pp. 2333-2342, 2012.

[17] A. Ali, G. Prasad, and R. Raghavan, "Threatened fishes of the world: Horabagrus brachysoma (Günther) (Bagridae)," Environmental Biology of Fishes, vol. 78, no. 3, p. 221, 2007.

[18] N. Sreeraj, R. Raghavan, and G. Prasad, "Some aspects of the fishery of the threatened yellow catfish Horabagrus brachysoma from Vembanad lake with a note on their landings at Vaikom, Kerala, India," Zoos' Print Journal, vol. 22, no. 4, pp. 26652666, 2007.

[19] R. Raghavan and A. Ali, "Horabagrus brachysoma," In: IUCN 2011. IUCN Red List of Threatened Species. Version 2011.2. 2011, http://www.iucnredlist.org/, 2012.

[20] A. Bhat, "A new report of Horabagrus brachysoma Jayaram, family Bagridae in Uttara Kannada District, Karnataka," Journal of the Bombay Natural History Society, vol. 98, no. 2, pp. 294-296, 2001.

[21] P. K. Talwar and A. G. Jhingran, Inland Fishes of India and Adjacent Countries, Oxford-IBH Publishing Co. Pvt. Ltd., New Delhi, India, 1991.

[22] Ø. Hammer, D. A. T. Harper, and P. D. Ryan, "Past: paleontological statistics software package for education and data analysis," Palaeontologia Electronica, vol. 4, no. 1, pp. XIX-XX, 2001.

[23] J. H. Zar, Biostatistical Analysis, Pearson Education, New Delhi, India, 4th edition, 1999.

[24] S. N. Sharina and Y. P. Kartavtsev, "Phylogenetic and taxonomic analysis of flatfish species (Teleostei, Pleuronectiformes) inferred from the primary nucleotide sequence of cytochrome oxidase 1 gene (Co-1)," Russian Journal of Genetics, vol. 46, no. 3, pp. 356-361, 2010. 
[25] X. L. Chen, T. Y. Chiang, H. D. Lin et al., "Mitochondrial DNA phylogeography of Glyptothorax fokiensis and Glyptothorax hainanensis in Asia," Journal of Fish Biology, vol. 70, pp. 7593, 2007.

[26] T. A. Hall, "BioEdit: a user-friendly biological sequence alignment editor and analysis program for Windows 95/98/NT," Nucleic Acids Symposium Series, vol. 41, pp. 95-98, 1999.

[27] S. F. Altschul, W. Gish, W. Miller, E. W. Myers, and D. J. Lipman, "Basic local alignment search tool," Journal of Molecular Biology, vol. 215, no. 3, pp. 403-410, 1990.

[28] R. C. Edgar, "MUSCLE: multiple sequence alignment with high accuracy and high throughput," Nucleic Acids Research, vol. 32, no. 5, pp. 1792-1797, 2004.

[29] K. Tamura, D. Peterson, N. Peterson, G. Stecher, M. Nei, and S. Kumar, "MEGA5: molecular evolutionary genetics analysis using maximum likelihood, evolutionary distance, and maximum parsimony methods," Molecular Biology and Evolution, vol. 28, no. 10, pp. 2731-2739, 2011.

[30] D. Posada and K. A. Crandall, "Selecting the best-fit model of nucleotide substitution," Systematic Biology, vol. 50, no. 4, pp. 580-601, 2001.

[31] A. P. H. Anvar, G. Prasad, N. K. Balasubramanyam, L. R. Chandran, and R. P. Raghavan, "Weight-length relation of an Asian catfish, Horabagrus brachysoma (Günther, 1864), (Siluriformes: Horabagridae) from rivers of the Western Ghats, Kerala, India," Acta Ichthyologica et Piscatoria, vol. 38, no. 1, pp. 41-44, 2008.

[32] R. Raghavan, "Yellow Catfish-a potential culture species in Southwestern India," Global Aquaculture Advocate, pp. 68-69, 2006.

[33] K. G. Padmakumar, L. Bindu, P. S. Sreerekha et al., "Breeding of endemic catfish, Horabagrus brachysoma in captive conditions," Current Science, vol. 100, no. 8, pp. 1232-1236, 2011.

[34] S. K. Sengupta, National Register of Large Dams, Central Water Commission, New Delhi, India, 2009, http://www.cwc.nic.in/ main/downloads/National\%20Register\%20of\%20Large\%20 Dams\%202009.pdf. 

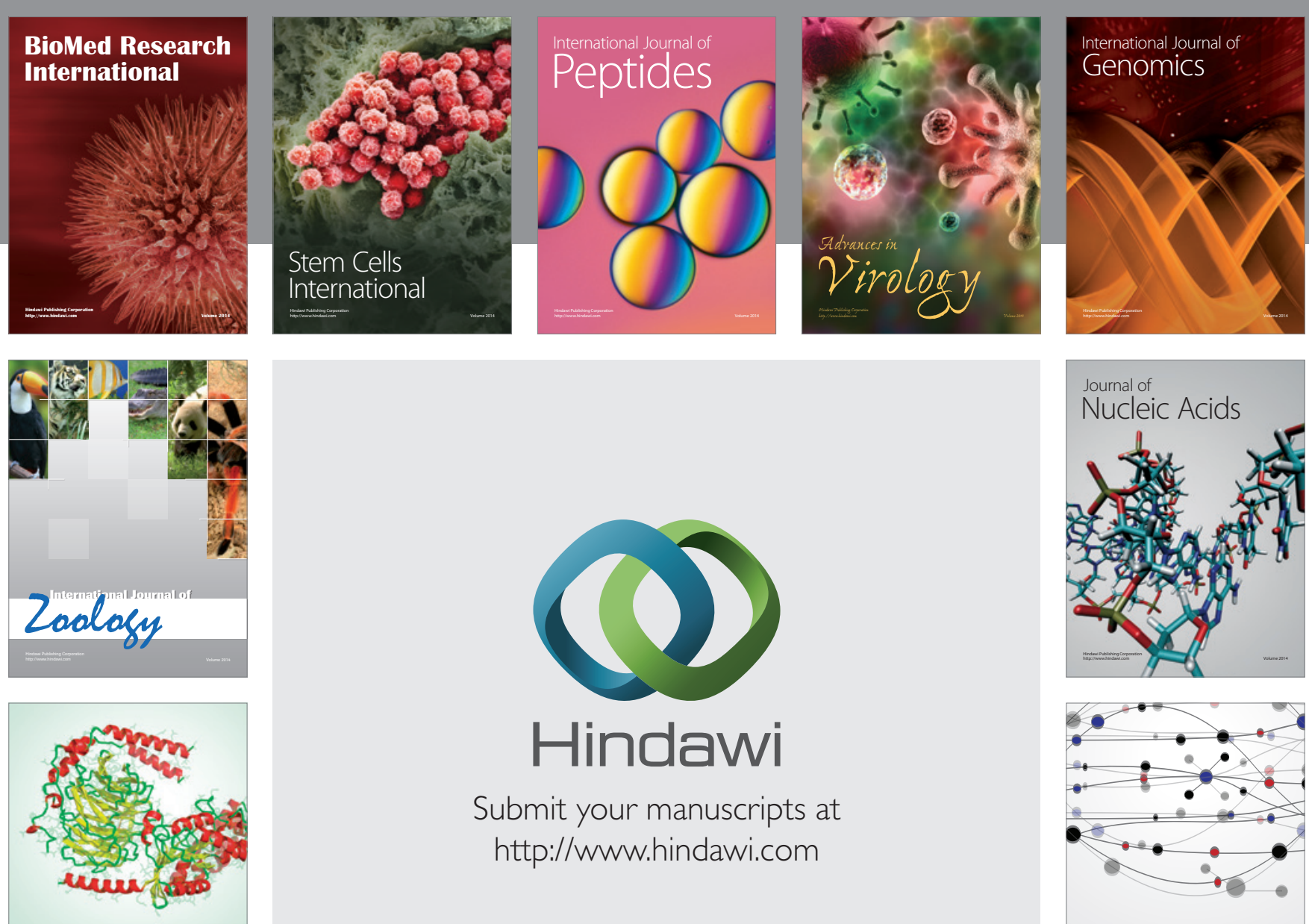

Submit your manuscripts at

http://www.hindawi.com

Signal ${ }^{\text {Jumal }}$ Transduction
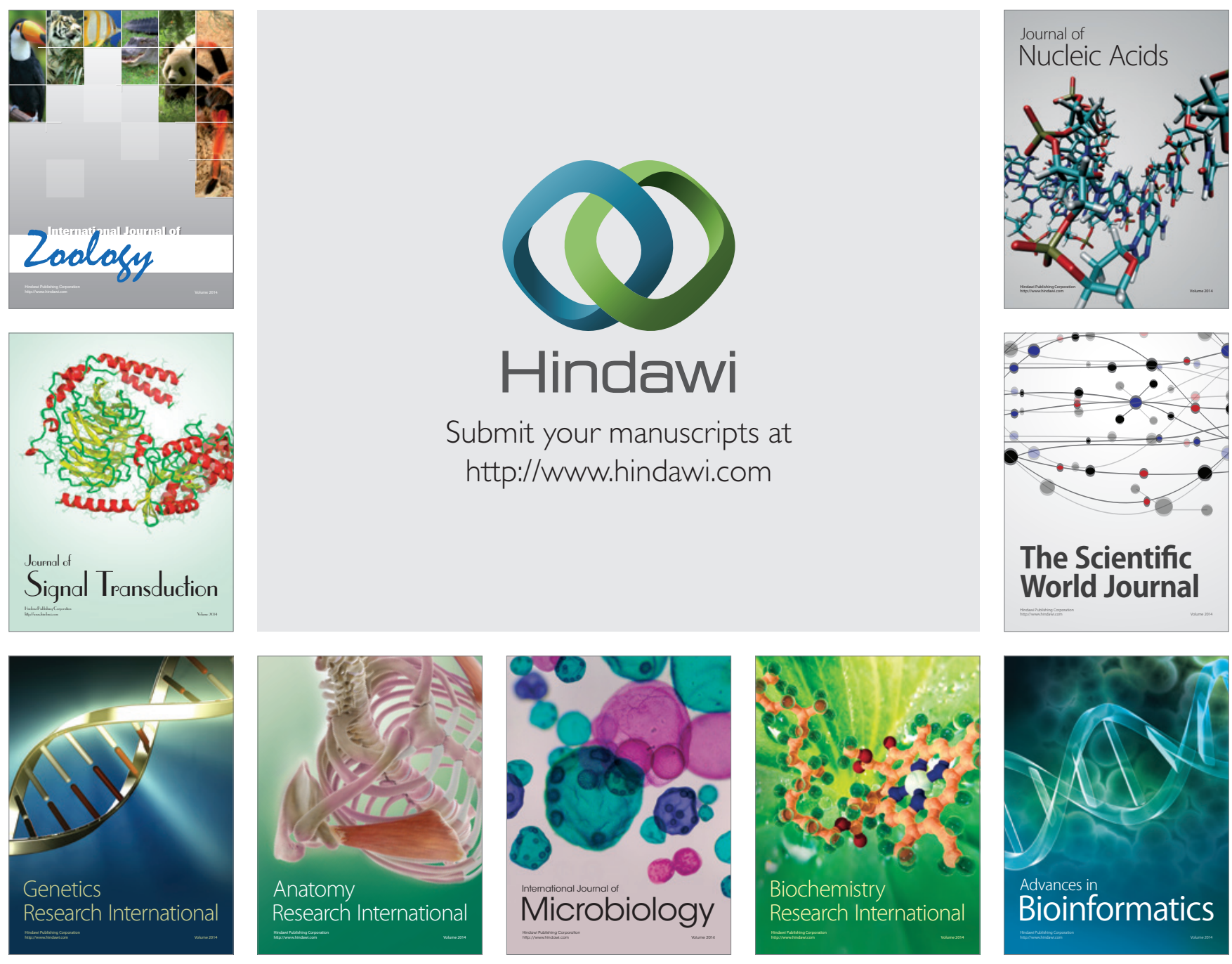

The Scientific World Journal
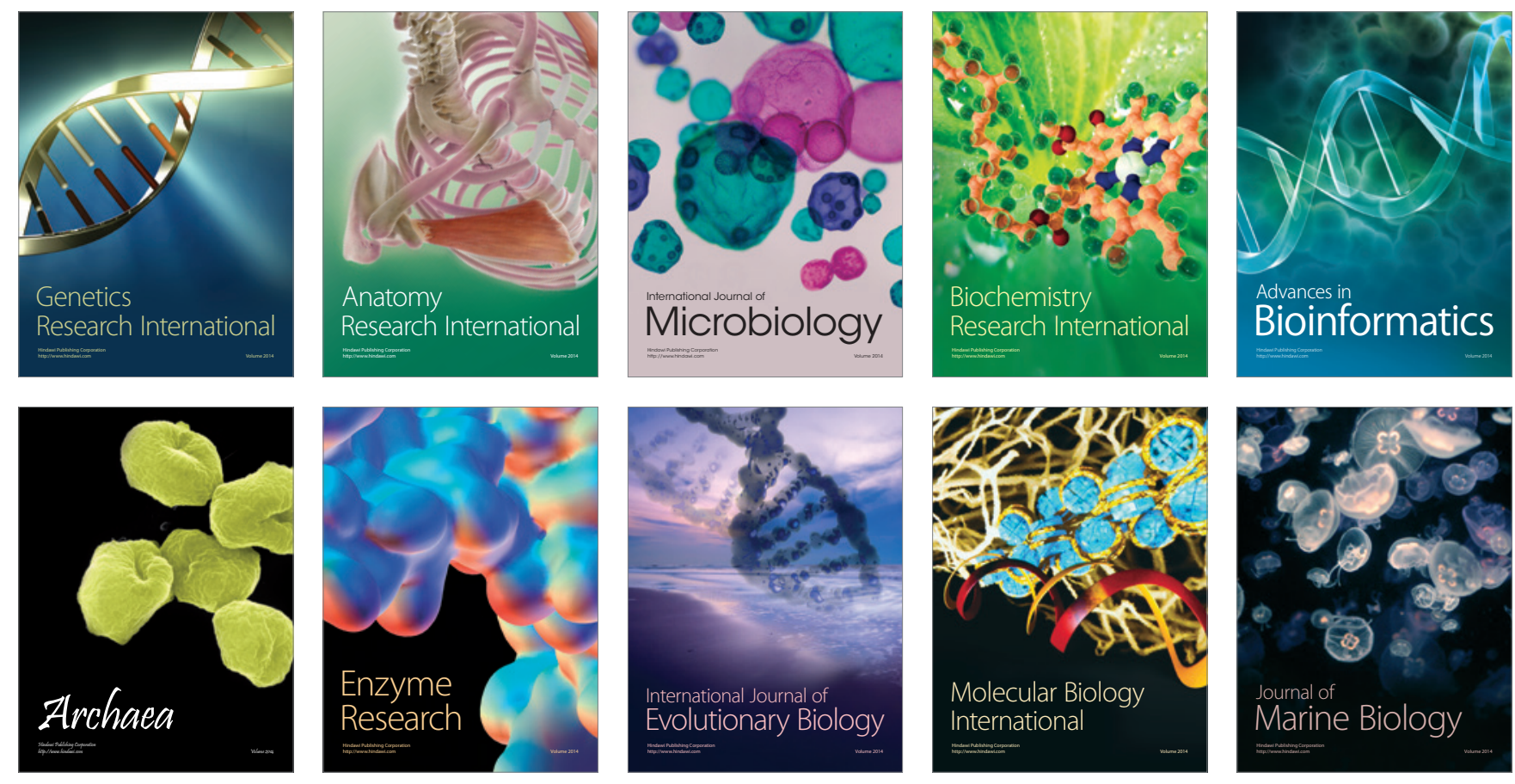